\title{
PALAEO
}

Palaeogeography, Palaeoclimatology, Palaeoecology 135 (1997) 163-177

\section{Environmental evolution during the Late Jurassic at Lavarone (Trento Plateau, Italy)}

\author{
Jesús E. Caracuel ${ }^{\mathrm{a}, *}$, Federico Olóriz ${ }^{\mathrm{b}, 1}$, Carlo Sarti ${ }^{\mathrm{c}, 2}$ \\ a Dpto. de Ingenieria, Cartográfica, Geodésica y Fotogrametria, E.P.S., Universidad de Jaén, Av. Virgen de la Cabeza 2 , \\ E-23071 Jaén, Spain \\ ${ }^{b}$ Dpto. de Estratigrafía y Paleontologia, Fac. de Ciencias, Universidad de Granada, Av. Fuentenueva $s / n$, \\ E-18002 Granada, Spain \\ ' Dip. Scienze Geologiche, Università di Bologna, Via Zamboni 67, I-40127 Bologna, Italy'
}

Received 30 May 1996; accepted 3 February 1997

\begin{abstract}
Four sections have been studied in the Monte Rust area (Lavarone, northern Italy) for the interpretation of depositional conditions. The biostratigraphic subdivision is based on more than 1400 stratigraphically controlled ammonite specimens, which enabled the recognition of five biozones in the Kimmeridgian and three in the Lower Tithonian. Three basic lithofacies are identified in the upper unit of the Rosso Ammonitico Veronese (nodular-marly, nodular-calcareous, and pseudonodular-calcareous-massive), which developed according to relative sea-level conditions. The depositional dynamics were closely related to increasing energy and winnowing during sea-level lows (nodular-calcareous ammonitico rosso), and the opposite during sea-level highs (nodular-marly ammonitico rosso). The highest energy conditions are assumed for the pseudonodular-calcareous-massive ammonitico rosso, revealing a probable interaction between tectonics and eustasy, and an increased mean rate of carbonate sedimentation. The cluster analysis of selected components of microfacies shows only minor fluctuations in a low-energy environment, and thus a rather variable relationship between micro- and macrofcatures in the ammonitico rosso facies studied. The correlation analysis between relative abundances of selected variables (components in the cluster analysis) has proven useful in interpreting fluctuations in energy conditions.

For the Kimmeridgian, deposits formed during sea-level highs (Uhlandi and Beckeri Chrons) are especially well correlated in the area, as well as elsewhere in the Western Tethys. The progressive, long-term sea-level fall during the Early Tithonian does not diminish the possibility for correlation in the epioceanic area studied. (C) 1997 Elsevier Science B.V.
\end{abstract}

Keywords: Ammonitico Rosso; depositional environment; Late Jurassic; Tethys; Trento Plateau

\footnotetext{
* Corresponding author. Phone: +34-53-212375; fax:+34-53-212343; e-mail: caracuel@ujean.es

${ }^{1}$ Phone and fax: $+34-58-243345$; e-mail: foloriz@goliat.ugr.es

2Phone: +39-51-354556; fax: +39-51-354522; e-mail: sarti@geomin.unibo.it.
} 


\section{Introduction and geological setting}

This paper deals with biostratigraphy and the interpretation of depositional conditions in the central part of the Trento Plateau, recorded in four sections located near Monte Rust (Lavarone, Province of Trento) (Fig. 1). We revisited some sections studied by Sarti (1986), Sarti (1993), whilst the section at the Bus di Pissavacca (BPV) at Bertoldi has been studied for the first time.

The succession studied belongs to the Rosso Ammonitico Veronese Formation (RAV), which is composed of ammonite-rich nodular marly limestones of the Middle-Late Jurassic. Outcrops are located in the Prealpi Veneto-Trentine (southern Alps). These facies are characterized by omission surfaces and hardgrounds on which ferruginous crusts and $\mathrm{Fe}-\mathrm{Mn}$ nodules occasionally developed during condensation events. The RAV reaches a maximum thickness of $30 \mathrm{~m}$, and ranges from Late Bajocian to Late Tithonian in age. Three units can be recognized in this formation: a lower unit (Calcari nodulari massicci), Bajocian-Bathonian in age; an intermediate unit (Calcari selciferi) of the Late Callovian (Erba, in Martire et al., 1991) to Oxfordian and/or earliest Kimmeridgian (Sarti, 1993); and an upper unit (Calcari nodulari) which is Kimmeridgian-Tithonian in age. The RAV crops out mainly between the Lago di Garda and Monte Grappa (northern Italy). This facies was deposited onto a distal pelagic-swell system or epioceanic plateau (Trento Plateau, Ruga di Trento or Piattaforma atesina).

The Trento Plateau was a structural high (Bahamian-type carbonate platform) until the late Early Jurassic. Subsequent platform drowning led to sedimentary starvation and pelagic carbonate deposition (Bosellini and Martinucci, 1975; Zempolich, 1993). Thus, the RAV marked the beginning of pelagic sedimentation on the platform, replacing shallower-water carbonates. Bosellini and Winterer (1975), and Winterer and Bosellini (1981) estimated the initial deposition depth for the RAV to be around $500 \mathrm{~m}$, based on present-day examples with similar depositional settings, and the character of sedimentation itself in the Venetian-Friulian area; these authors took into account the fact that distal turbidites from the Friuli Platform occasionally reached the Trento Plateau. Therefore, assuming a distance of about $50 \mathrm{~km}$ between the drowning Trento Plateau and the sublittoral Friuli Platform, and a mean dip of $1^{\circ}$ in the talus, they estimated a depositional depth of around $500 \mathrm{~m}$.

The RAV shows a significantly decreased carbonate sedimentation rate, which increased during deposition of the Maiolica (Biancone) facies - a Nannoconus and calpionellid-rich white-grey mudstone with episodic incipient nodularization and cherty nodules and horizons (Castellarin, 1972; Ferrari, 1982; Clari and Pavia, 1987; Cecca et al., 1992).

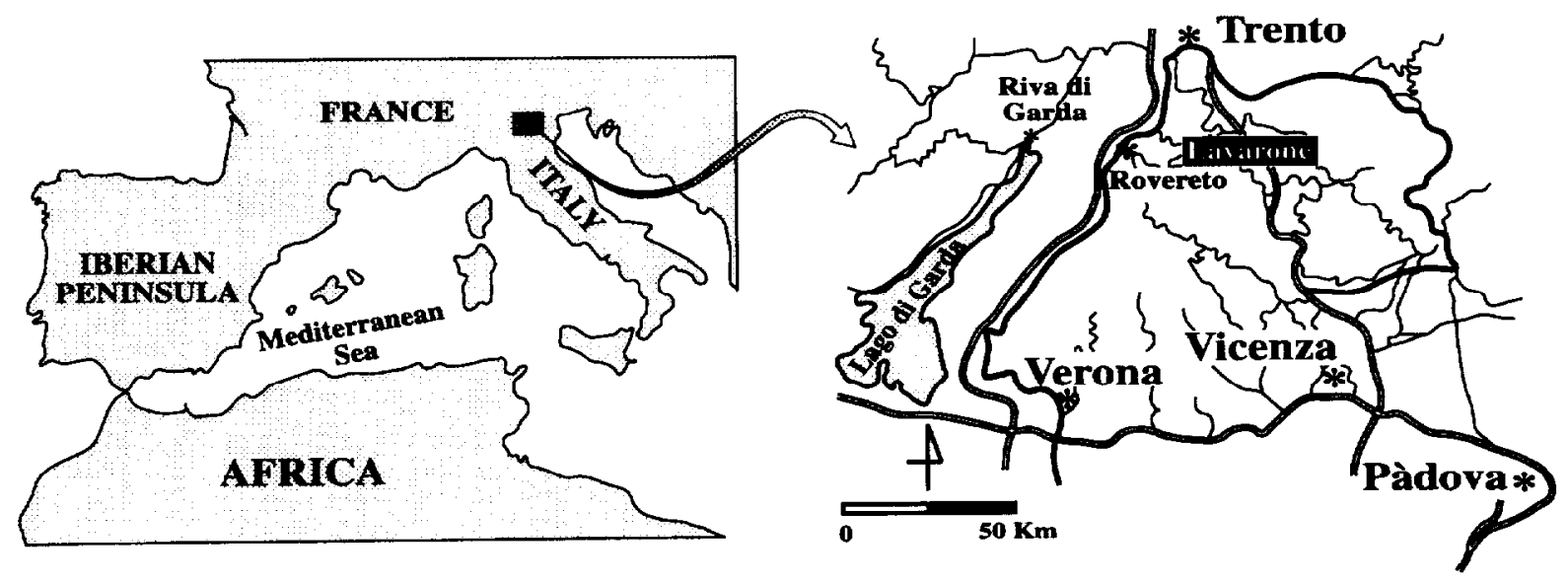

Fig. 1. Location of the study area. 
Some present-day examples of nodular-calcareous deposits have been reported from the Ionian Sea (Müller and Fabricius, 1974; Biju Duval et al., 1983). These authors stressed the role of early sedimentation during nodule formation through direct precipitation of $\mathrm{Mg}$-rich seawater. According to Müller and Fabricius (1974), this should be favoured by high salinity and temperature, and low to non-sedimentation. Mullins et al. (1980) stressed nodular submarine cementation of carbonate sediment as a way to produce nodularization favoured by combined bioturbation and bottomcurrent winnowing, which slows the sedimentation rate while increasing porosity.

Ancient, nodular limestones (ammonitico rosso and related facies) are assumed to have originated in a number of ways and environmental settings [see Farinacci and Elmi (1981) for extended treatment]. In such a context, the RAV resulted from slow scdimentation, slight bottom currents and bioturbation, which provoked hiatuses of different magnitudes between episodes of active deposition. One of the more significant hiatuses appears between the RAV and the underlying Calcari Grigi Formation (late Early Jurassic), or the Oolite di San Vigilio (Toarcian-Aalenian), spanning the Domerian/Aalenian to the Late Bajocian. Condensed deposits and stratigraphic gaps in the RAV (the latter especially developed in the upper unit, to which the sections studied at Monte Rust belong), determine the variablc thickncsses of the identified ammonite biozones in the Trento Plateau, even when sections close together are considered.

At Monte Giovo, located on the western margin of the Trento Plateau, the base of the upper unit of the RAV (Middle Oxfordian, Transversarium Zone) directly overlies Toarcian-Aalenian deposits of the Oolite di San Vigilio (Sarti, 1993). In this case, not only the previously mentioned persistent hiatus appears, but also another significant one covering the Bajocian-Oxfordian, as well as other minor ones within the RAV.

The RAV was deposited on a distal pelagicswell system located in the northern Apulian Block (Fig. 2) which represented a part of the North African continental margin. Within the epioceanic fringe, this distal pelagic-swell system was sur- rounded by basins extending hundreds of kilometres, receiving pelagic marls and mudstones with occasional siliceous horizons. This pelagic-swell system therefore constituted a palaeogeographic unit free from terrigenous inflow and allochthonous carbonates that accumulated in surrounding troughs (Lombard Basin westwards and the Belluno Trough eastwards). The latter, especially, received sedimentation from the adjacent Friuli carbonate platform. Deposition in the Trento Plateau was thus exclusively pelagic and subject to oceanic currents.

The thickness of the upper unit in the Trento Plateau varies from $16 \mathrm{~m}$ in the east at Monte Grappa to $2 \mathrm{~m}$ in the west at Monte Giovo. The RAV succession in the Trento Plateau has been differentiated in type "A" and "B" successions (Sarti, 1985). Between the lower Calcari nodulari massicci and the upper Calcari nodulari, the type "A" succession shows a significant, mineralized hardground in which neomorphic shells of ammonites and belemnite rostra are concentrated (Cima di Campo di Luserna section, Sarti, 1993). On the other hand, in the type " $B$ " succession seen in the Lavarone sections, cherty limestones (the intermediate unit of the RAV: Calcari selciferi) are intercalated between the Calcari nodulari massicci and the overlying Calcari nodulari. Thickness in these siliceous deposits varies along the Trento Plateau, locally reaching $10 \mathrm{~m}$. At the top of this unit is a bentonite-rich horizon (Bernoulli and Peters, 1970; Bernoulli and Peters, 1974).

\subsection{Studied sections and remarks on biostratigraphy}

In the Monte Rust area, Comune di Lavarone (Caldonazzo topographic sheet 36-I) in the province of Trento, four sections (MR-1, MR-2, FAU, and BPV) were studied, making complementary observations at many other points. All sections were located in the central Trento Plateau; the eastern BPV section was located 2.5 and $2 \mathrm{~km}$ east from the FAU and the MR-1 and MR-2 sections, respectively. The succession studied (upper unit of the RAV) dates from the Early Kimmeridgian (Strombecki Chron)-Early Tithonian (Verruciferum/Semiforme Chron) and has a maxi- 


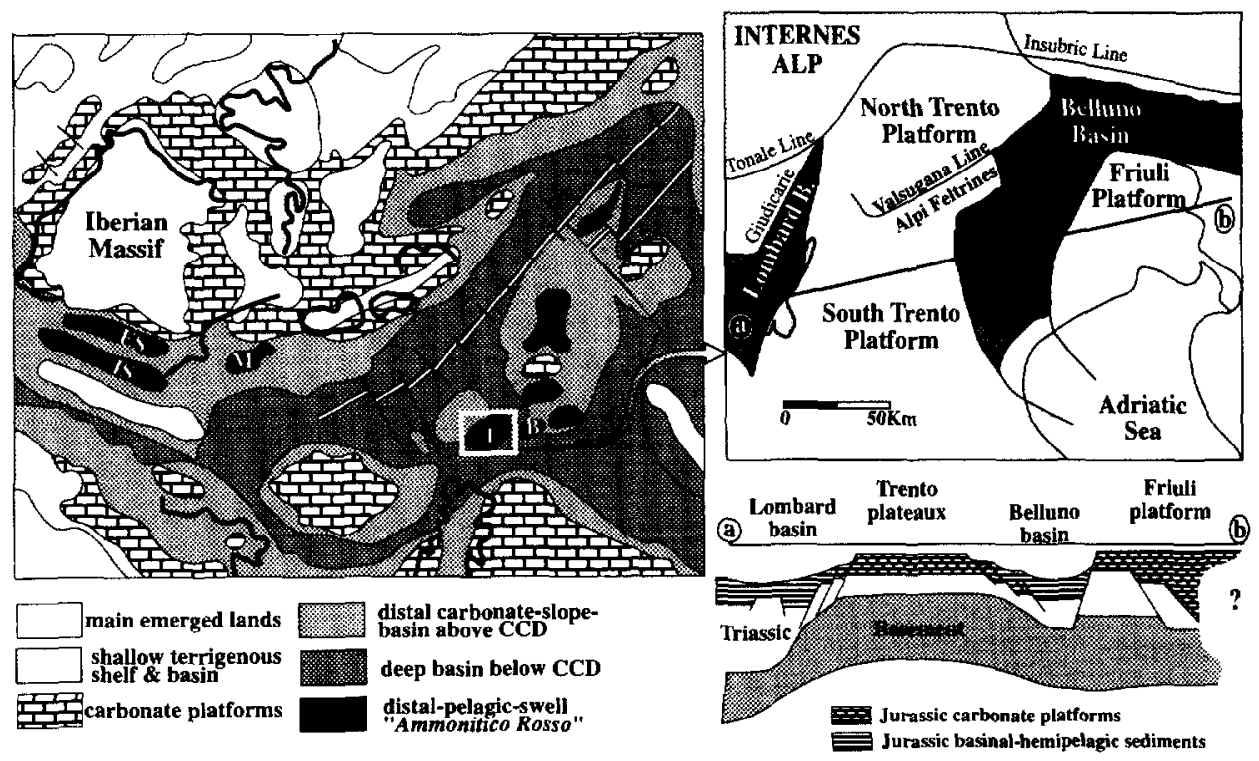

Fig. 2. Left: Palaeogeographic sketch of the Western Tethys in the Kimmeridgian (modified from Cecca et al., 1992), showing main areas of outcropping ammonitico rosso facies in epioceanic environment which are here considered; $T=$ Trento Plateau; $B=B a k o n y$ Mts.; $M=$ Mallorca Island; $E S=$ External Subbetic; $I S=$ Internal Subbetic.

Right: Regional map and synthetic profile for the Trento Plateau and adjacent basins (Lombard and Belluno), and the Friuli Platform.

mum thickness of $7 \mathrm{~m}$ in the FAU section. The westernmost section, MR-2, $6.35 \mathrm{~m}$ thick, is the most complete and therefore was more intensively sampled and used as the reference section. In the MR-1 section, the lower boundary with the Caleari selciferi does not crop out, but the upper section (Verruciferum/Semiforme Zone) is the most complete. The BPV section shows the most condensed Kimmeridgian, especially in the Herbichi and Acanthicum Zones.

In the MR-2, BPV, and FAU sections, the upper unit of the RAV overlies the Calcari selciferi, the top of which (bentonite-rich horizon) served as a guide-level for litho-correlation and biostratigraphic sampling. The contact of the RAV with the overlying Biancone was found in situ in the MR-1 and BPV sections alone. According to the data obtained, the lithostratigraphic and biostratigraphic correlations are reliable between sections.

Around 1500 megainvertebrate specimens, mainly ammonites, have been collected with a $10-15 \mathrm{~cm}$ sampling-interval (Fig. 3 ). The ammonite assemblages show the Mediterranean character typical in Upper Jurassic ammonites from the epioceanic Western Tethys in the Umbria-Marche
(Cecca et al., 1990), Venetian Alps (Sarti, 1988, 1993), southern Spain (Subbetic Zone, Enay and Geyssant, 1975; Olóriz, 1978; Olóriz and Tavera, 1981, 1989; Caracuel, 1996), and Hungary (Bakony Mts., Fözy, 1990), and dominant in Bulgaria (Sapunov, 1977a,b).

Based on subdivisions proposed by Sarti (1988, 1993), the following ammonite-defined bio-chronostratigraphic units have been identified: the Strombecki, Herbichi, Acanthicum, Cavouri and Beckeri/Pressulum Zones in the Kimmeridgian, and the Hybonotum, Albertinum and Semiforme/ Verruciferum Zones in the Lower Tithonian (Fig. 3). Selected ammonites, among those recorded, which are significant for bio-chronostratigraphy in the study area and enable correlations within the epioceanic Western Tethys, include:

Strombecki Zone. Metastreblites sp., Nebrodites macerrimus (recorded for the first time in the Trento Plateau), and Lessiniceras sp., all of these recorded below ammonite assemblages belonging to the Divisum Chron in the standard bio-chronostratigraphic scale (columns 1 and $3-6$ in Hantzpergue et al., 1991).

Herbichi Zone. Pseudosimoceras stenonis (lower 


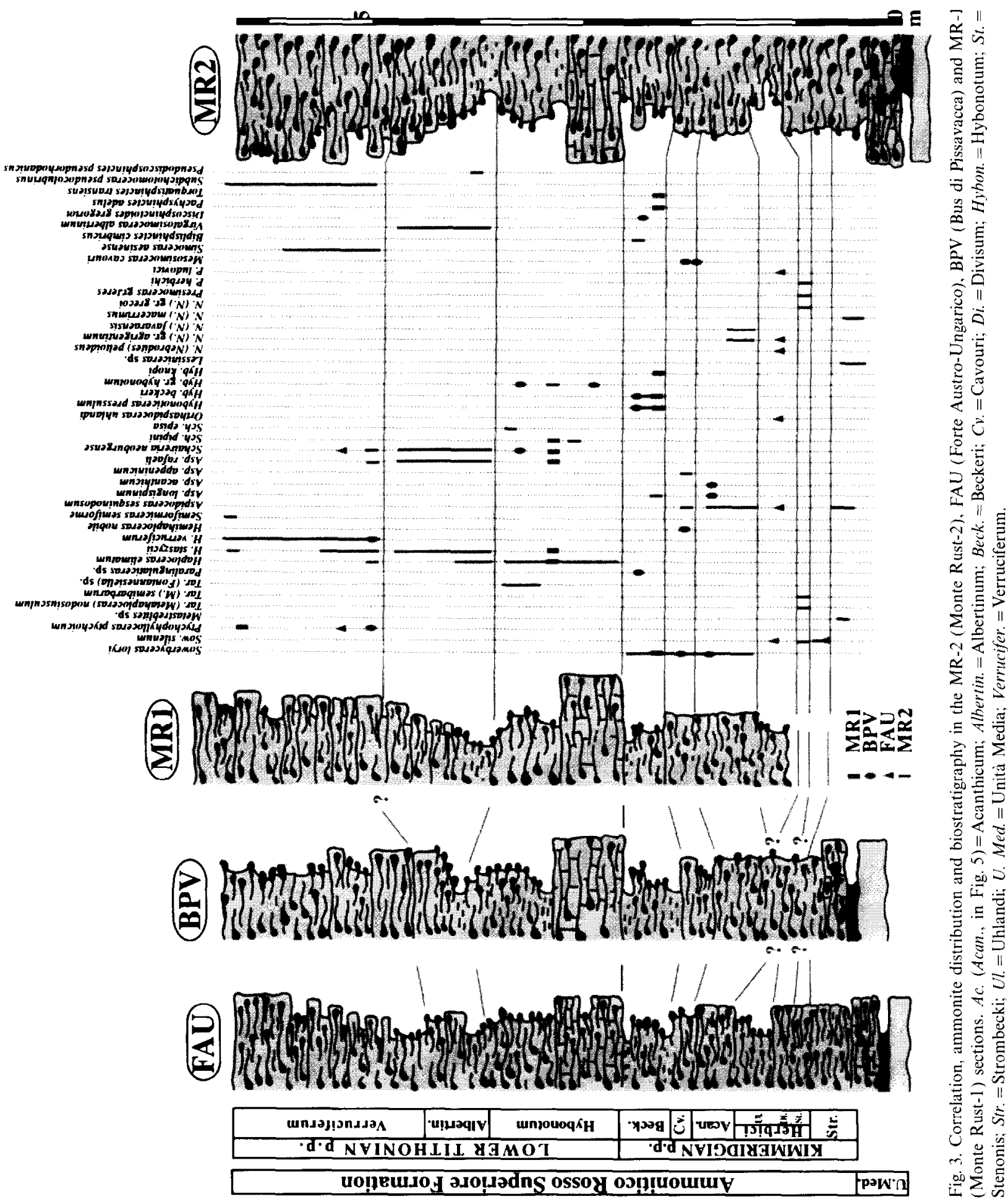




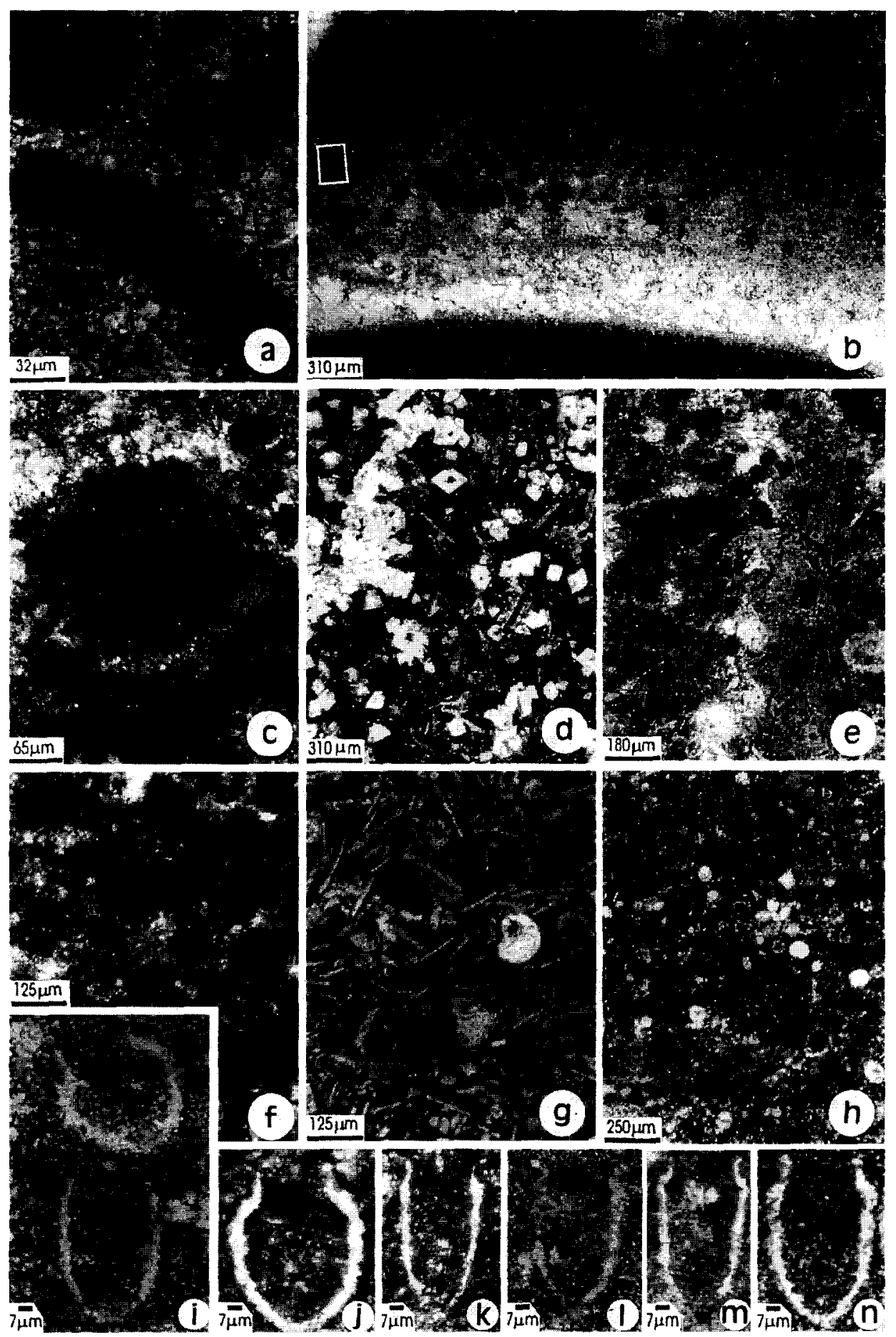


part, Stenonis Subzone), Presimoceras spp. and Metahaploceras (cf. nodosiusculum, semibarbarum). Increasing abundance of Presimoceras and Nebrodites characterizes the upper part of this zone (Divisum Chron, see above). Aspidoceras uhlandi characterizes the uppermost Herbichi Zone, the upper boundary of which is well identified by the replacement of Sowerbyceras silenum by loryi.

Acanthicum Zone. Aspidoceras longispinum, A. sesquinodosum, and $A$. acanthicum (recorded in the upper part), the highest Nebrodites and the lowest Schaireria and Discosphinctoides. Sowerbyceras loryi is very abundant at the middle part of this zone.

Cavouri Zone. Mesosimoceras cavouri and risgoviense, as well as the first record of Hemihaploceras and perisphinctids, which characterize the uppermost Kimmeridgian.

Beckeri/Pressulum Zone. The first record of Hybonoticeras defines the lower boundary. Hybonoticeras (pressulum and beckeri groups), Aspidoceras appenninicum, Hemihaploceras, Paralingulaticeras and the uppermost Sowerbyceras loryi characterize this zone, together with typical Upper Kimmerigian Taramelliceras, Pseudowaagenia and perisphinctids.
Hybonotum Zone. Hybonoticeras (group of hybonotum), Haploceras (elimatum, staszycii), together with Lower Tithonian perisphinctid assemblages (Lithacoceras, Pseudodiscosphinctes, Subplanitoides, Parakeratinites, Pseudokatroliceras). Tithonian Schaireria are common and the species episa was recorded for the first time in the epioceanic Tethys.

Albertinum Zone. First record of Virgatosimoceras (albertinum; rothpletzi from the upper part) and less common Semiformiceras darwini, together with Haploceras cassiferum, Pseudodiscosphinctes pseudorhodanicus, Subplanitoides schwertschlageri (upper part), "Subplanitoides" and related macroconchs.

Semitorme/Verruciferum Zone. Haploceras verruciferum s.str., less common Semiformiceras semiforme and then Simoceras aesinense. Lower Tithonian epioceanic perisphinctids were common.

\section{Facies and depositional environments}

In the sections studied, three main lithofacies were recognized and correlated on the basis of ammonite biostratigraphy (Figs. 3 and 5): (1) the Nodular-Marly-Facies/NMF (wackestones and

Plate I.

a. Close-up view of bioerosion (micritized tubes) on mollusk shell at right (b); MR-2 section, Horizon 2, NCF, Strombecki Zone $(\times 169)$.

b. Mollusk shell showing bioerosion (white rectangule enlarged in (a)). and microbial pellets at the top: MR-2. section. Horizon 2 , NCF, Strombecki Zone $(\times 17)$.

c. Micritized pellet or microbioturbation; MR-2 section, Horizon 25, NCF, Verruciferum Zone $(\times 85)$.

d. Euhedral dolomite rombs in wackestone of the upper part of the Russo Animonitico Veronese; BPV section, Horizon 20, NCF, Verruciferum Zone $(\times 17)$.

e. Pellet-rich wackestone showing intensive bioerosion of bioclasts (aptychus); MR-2 section, Horizon 12, PSCMF, Hybonotum Zone $(\times 30)$

f. Bioclast-rich wackestone showing mineralized Protoglobigerina; BPV section, Horizon 2, NCF, lower Herbichi Zone ( $\times 42$ ).

g. Bioclast-rich packstone showing random orientation of Saccocoma and filaments; BPV section, Horizon 8 , NMF, lower Beckeri Zone $(\times 42)$.

h. Bioclasts-rich wackestone (ground-facies) showing mainly radiolaria, Globochaete, and pellets; MR-2 section, Horizon 2 , NCF, Strombecki Zone $(\times 21)$.

i. Oblique section of small Tintinnopsella carpathica (bottom) and small isometric Calpionella alpina (top): BPV section, Horizon 23, Biancone facies, earliest Berriasian $(\times 212)$.

j. Sub-isometric Calpionella alpina of intermediate size; BPV section, Horizon 23, Biancone facies, earliest Berriasian $(\times 212)$

k. Crassicollaria colomi; BPV section, Horizon 22, Biancone facies, earliest Berriasian $(\times 212)$.

1. Small Crassicollaria intermedia; BPV section, Horizon 22, Biancone facies, earliest Berriasian $(\times 212)$

$\mathrm{m}$. Small Crassicollaria massutiniana; BPV section, Horizon 22, Biancone facies, earliest Berriasian $(\times 212)$.

n. Crassicollaria parvula; BPV section, Horizon 23, Biancone facies, earliest Berriasian $(\times 212)$. 
occasionally packstones), which are well represented in the Herbichi Zone (Uhlandi Subzone), in the Beckeri Zone, and in some intervals in the Hybonotum and Albertinum Zones (Lower Tithonian); (2) the Nodular-CalcareousFacies/NCF (mainly packstones, and some wackestones), which could be considered the typical facies, is widespread in all sections, and may have stromatolitic overgrowths; and (3) the Pseudonodular-Calcareous-Massive-

Facies/PSCMF (mainly packstones, and some wackestones), which developed only at the base of the Hybonotum Zone (Lower Tithonian).

As usual in ammonitico rosso (Olóriz et al., 1995b), textures are mainly wackestones, secondarily packstones, and occasionally grainstones when intraclast-rich (Saccocoma- and filament-rich horizons) bed tops are considered; mudstones are commonly related to intensive bioturbation. More significant microfossils are Globochaete, filaments (both especially from the Middle Kimmeridgian upwards; Plate Ig), Protoglobigerina (LowerMiddle p.p. Kimmeridgian; Plate If ), radiolaria (top of the intermediate unit and bottom of the upper unit; Plate Ih), Saccocoma (Plate Ig), early growth stages of ammonites and aptychi. Less common are Stomiosphaera, Cadosina, bivalves, gastropods, pedunculate crinoids, and foraminifera (including Spirillinidae, Trocholinidae, and occasionally microgranular ones).

In the microfacies analysed, $\mathrm{Fe}-$ and Mn-oxyhydroxides, aggregate grains and common to abundant pellets are persistently recorded, but pellet-poor horizons as well as microbial pellets (Massari, 1981) have been identified at the base of the succession. In general, Lower and Middle Kimmeridgian fabrics show microbially active biosedimentation resulting in stromatolitic crusts and bothrolitic overgrowths, similar to those studied by Massari (1981), Massari (1983). Bioclast micritization is widespread throughout the succession, as is bioerosion (Plate Ia, b and e) and/or subsolution (sensu Hollmann, 1962, 1964). In the upper part of the succession, recrystallisation and scarce euhedral dolomite rhombs developed below horizons with incipient dolomitization in the overlying Biancone (Plate Id).

Microfacies in the lowermost Biancone in the
BPV section show calpionellid-rich wackestones, with common Stomiosphaera and Cadosina, few radiolaria, and rare foraminifera (Spirillina); scanty echinoid plates and aptychi are also present. Calpionellid assemblages evolved from relatively diversified Crassicollaria (massutiniana, colomi, and gr. intermedia; Plate Ik-III) of small to intermediate size $(55-80 \times 35-55 \mu \mathrm{m})$, together with scarce and mainly isometric forms of Calpionella alpina of intermediate size $(50-70 \times 50-70 \mu \mathrm{m})$, as well as rare, small Tintinnopsella (Plate Ii) of the carpathica group $(60-65 \times 35-40 \mu \mathrm{m})$, to increasing isometric forms of mid-size $(60 \times 60 \mu \mathrm{m})$ Calpionella alpina (Plate $\mathrm{I} \mathrm{j}$ ) in co-dominance with Crassicollaria parvula $(70-75 \times 45-50 \mu \mathrm{m})$ (Plate In) and uncommon and slightly larger Tintinnopsella carpathica. These two calpionellid assemblages show the well-known turnover between the upper Crassicollaria and lowermost Calpionella zones. Similar, small-sized calpionellid assemblages from Mallorca have recently been interpreted as being typical epioceanic populations (Olóriz et al., 1995a). According to calpionellid biostratigraphy in neighbouring areas in the Western Tethys (Olóriz and Tavera, 1981: Tavera et al., 1994; Olóriz et al.. 1995a), the most probable age for the base of the Biancone in the BPV section is the earliest Berriasian.

The numerical analysis of microfacies components in ammonitico rosso facies was first approached by Olóriz et al. (1995b) to interpret relationships between micro- and macrofeatures in these condensed deposits. This analysis showed not only microfacies groupings according to stratigraphy and depositional conditions, but also dense clustering caused by synsedimentary and diagenetic dissolution as well as by differentiated bioturbation and time-averaging. For alternating resedimented/condensed deposition (macrofeatures; type-facies in Olóriz et al., 1995b), these authors applied principal-components analysis, which indicated a homogeneous skeletal composition but heterogeneous fabric (microfeatures).

Without significant resedimentation phenomena, we carried out numerical analyses (cluster $Q$-mode) on the RAV, based on quantification of Protoglobigerina, Globochaete, pellets, bioturbation, lamination, and Saccocoma + filaments + 
aptychi $(S+\mathrm{F}+\mathrm{A})$ under the microscope, in terms of rare $(<5 \%)$, scarce $(10-15 \%)$, common $(20-30 \%)$ and abundant $(>30 \%)$.

The MR-1 dendrogram in Fig. 4 shows separate clustering of NCF according to reversal Protogrobigerina/Globochaete ratio (bunch 2-5), and then increasing radiolaria and decreasing bioturbation for separating bunches 10-17 and 11-13. Separate clustering also affects NMF throughout variation in content of pellets and of the combination of $S+\mathrm{F}+\mathrm{A}$ in bunches 1-5, 6-18 and 7-16. The MR-2 dendrogram reveals a major bunching which is based mainly on floating-bioclast abundance, and thus is controlled by energy. With some exceptions, the major bunch 1-7 broadly correlates with low-energy conditions (Fig. 5). Similar composition for the NMF, directly over PSCMF, in sections MR-1 and MR-2, contrasts with variable bioclast composition in the PSCMF, depending on energy. The clustering of lithofacies in bunch 12-21 in the MR-2 dendrogram is consistent with lower-energy conditions for deposition of PSCMF in this section. Intermediate-energy conditions are assumed for the BPV section according to the clustering of variable lithology in bunch 7-11. Nevertheless, the BPV dendrogram shows a clear clustering of NMF (9-21, 10-19 and 15-16), as well as a major clustering (3-11 vs. 10-24) controlled by floating-bioclast abundance, thus indicating generally higher energy throughout the BPV section.

The cluster analysis (Fig. 4) revealed the following: (a) uniformily in microfacies composition; (b) slight effect of the reversal in the Protoglobigerina/Globochaete ratio (Acanthicum Cavouri Zones), although the age discrimination for these microfacies components has not previously been demonstrated for the Kimmeridgian (this can be obscured by the significance of floating bioclasts in the BPV section); and (c) a relatively high clustering of NCF occurs, with local variations (MR-1 vs. MR-2 sections), admitting transition to NMF (10-17 in MR-1 section; 3-7, 16-20 and 10-25 in MR-2 section; 3-9, 5-6 and 10-18 in BPV) as well as to PSCMF (8-13 in MR-1 section; 12-21 in MR-2 section; 7-12 in BPV section); (d) the clustering obtained points to subtle changes in low-energy conditions as the main factor controlling distribution of microscopic components in lithofacies; and (e) the restriction of cluster analysis to only 6 workable variables fits well with the lowenergy conditions inferred, and contrasts with the

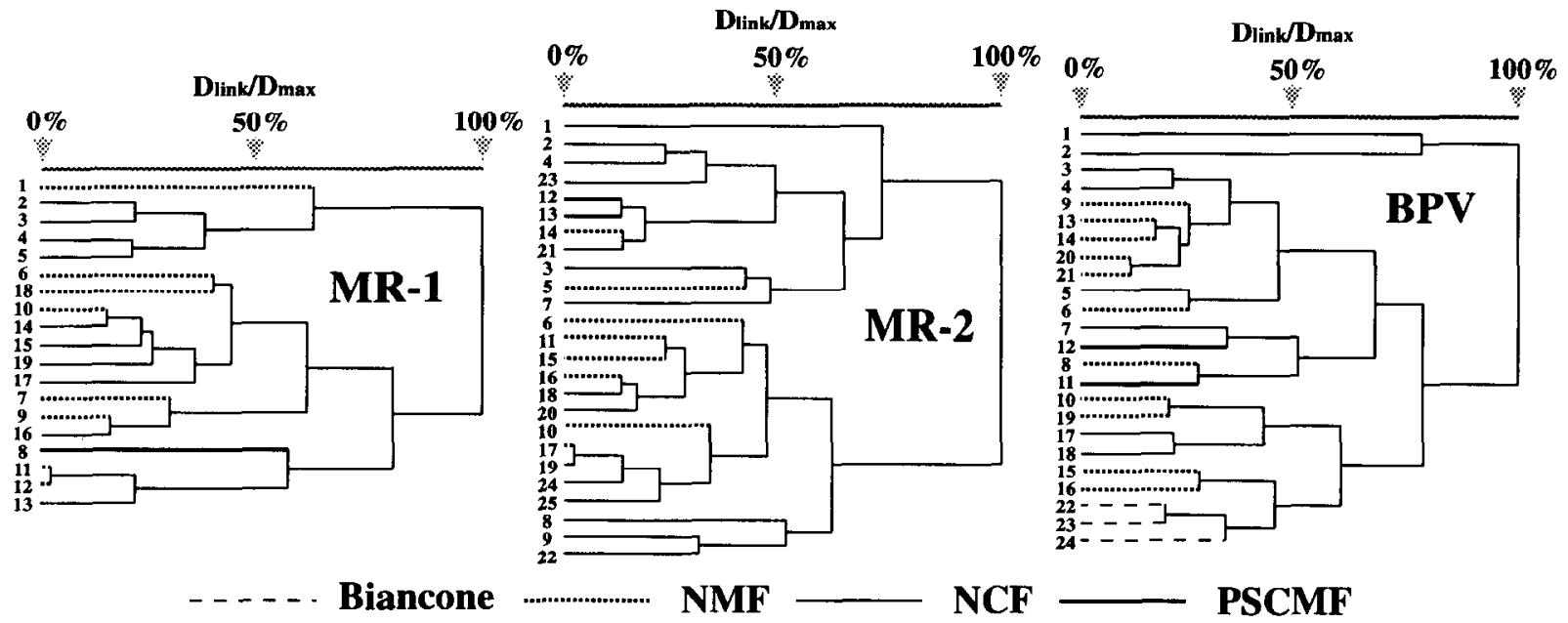

Fig. 4. Dendrograms of cluster analysis obtained from the study of 6 variables (semiquantitative estimation by microscope of percentage of: Protoglobigerina, Globochaete, pellets, bioturbation, orientation of bioclasts, and the Saccocoma + Filaments + Aptychy) and 19 cases in the MR-1 section, 25 in the MR-2 section, and 24 in the BPV section. Missing data were casewide deleted. Amalgamation criteria were clustered as weighted pair-group averaged, considering Euclidean metric distances. NMF, NCF, and PSCMF, for recognized type-facies in the studied Ammonitico Rosso Veronese. See text for explanation. 


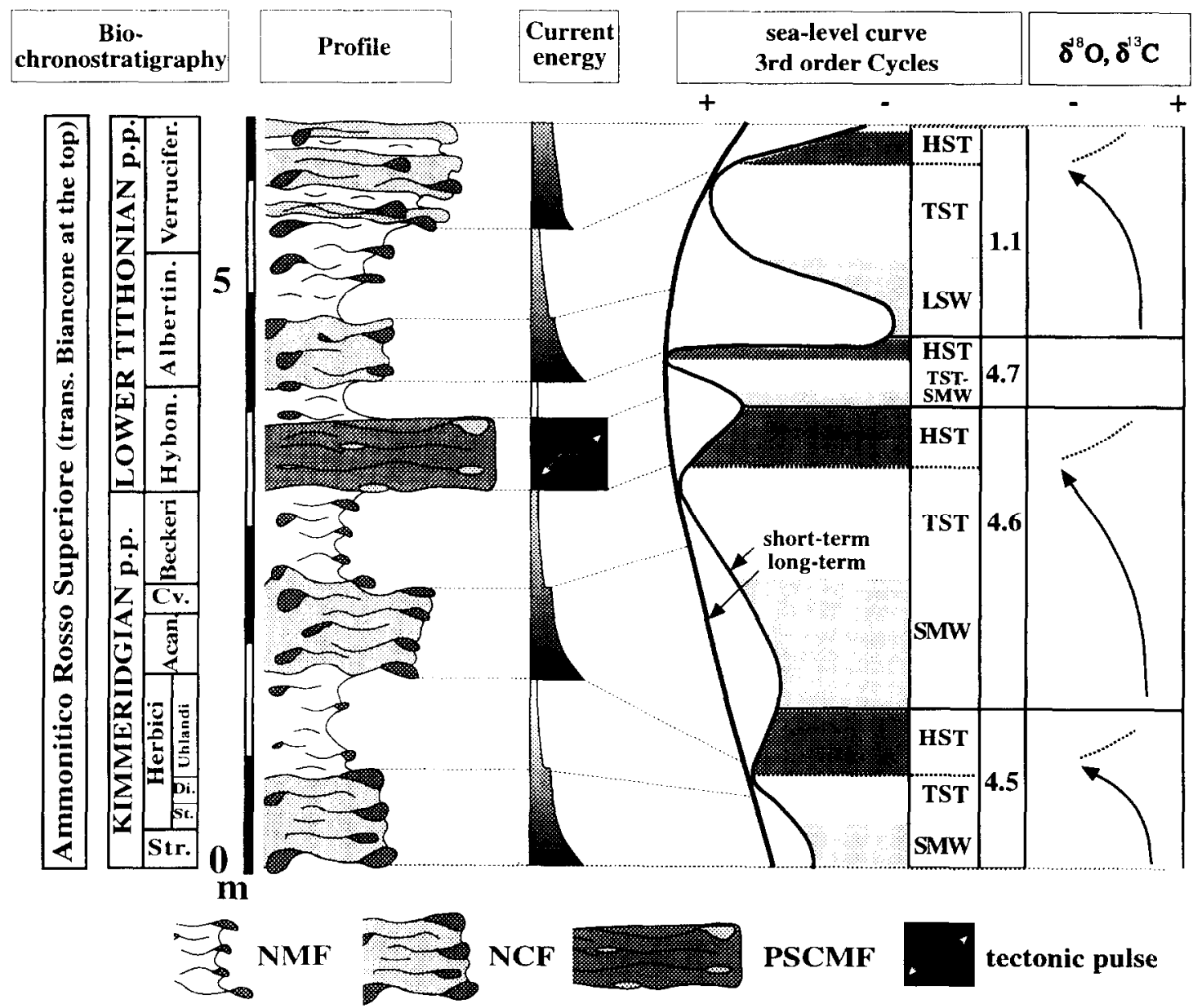

Fig. 5. Synthetic lithostratigraphic profile of the Kimmeridgian-.. Lower Tithonian studied, and proposed correlation to the sea-level curve as proposed by Haq et al. (1988) slightly adapted for Iberia in Marques et al. (1991); facies distribution (NMF, NCF, and PSCMF): and energy of currents as inferred from microfacies analysis. Note higher-energy conditions inferred for PSCMF, probably due to a tectonic pulse. Trends to lighter $\delta^{18} \mathrm{O}$ and $i^{13} \mathrm{C}$ isotopes correlate well with sea-level rises. See text for explanation. Abhreviations as in Fig. 3

cluster analysis on 17 variables made by Olóriz et al. (1995b) in higher-energy ammonitico rosso from the Tithonian in Mallorca.

Complementary inlormation was obtained applying correlation analyses to relative abundances of the variables Protoglobigerina, Globochaete, pellets, bioturbation, bioclast orientation and the combination of $S+\mathrm{F}+\mathrm{A}$. The scarce but constant record of radiolaria would have reduced correlation indices, and was therefore removed. More relevant results from the correlation analyses were: (a) the negative and low-range fluctuating correlation between bioclast orientation and bioturbation $(-0.698,-0.682$, and -0.766 in sections MR-1, MR-2 and BPV, respectively); (b) the negative correlation of bioclast orientation and abundance (not only presence; absence) of $S+\mathrm{F}+\mathrm{A}$ in the close MR-1 $(-0.209)$ and MR-2 $(-0.207)$ sections, and the slightly positive correlation $(0.177)$ in the separate BPV section; (c) the positive correlation between a large number of Globochate and the $S+\mathrm{F}+\mathrm{A}$ in the MR-1 (0.546), MR-2 (0.438), and BPV (0.282) sections; and (d) the negative correlation of 
Globochaete $(-0.544,-0.628$, and -0.390$)$ and the $S+\mathrm{F}+\mathrm{A}(-0.434,-0.124$, and -0.016$)$ with respect to Protoglobigerina, which disappeared around the Middle Kimmeridgian.

All these features are interpreted as having been caused by fluctuations in energy levels [except for point (d)], the fluctuations being related to differential sea-bottom topography for a given relative sea level (see below). Higher-energy conditions forcing bioclast orientation persistently inhibited bioturbation (a), thus bringing about an active sweeping of the $S+\mathrm{F}+\mathrm{A}$ that lead to low but differential $S+\mathrm{F}+$ A concentrations at particular horizons and settings (b). Conversely, bioturbation increased under low-energy conditions (a), favouring random bioclast orientation, as well as deposition of easily transportable bioclasts such as Globochaete and the $S+F+A$ (c). Stratigraphically, Protoglobigerina was replaced by Globochaete and Saccocoma, but later than postulated by Dromart and Atrops (1988). Only minor fluctuations seem to balance the record of Protoglobigerina and Globochaete, where these coexisted.

One of the factors assumed to force lithofacies evolution is the fluctuation in the relative sea level. Proposed global sea-level curves can be generally accurate but distorted in detail due to imprecise biostratigraphy and local/regional tectonics (Hallam, 1988). If high biostratigraphic resolution is available (e.g., at the ammonite zone/subzone level ), biostratigraphy ("procedure inverse" in Vail et al., 1987, p. 1315) is one way to test the possibility of a correlation between local stratal patterns, and facies, and those expected from published global eustatic curves. Interactions between tectonics and eustasy during the Late Jurassic are usually recognized in the Western Tethyan Iberian palaeomargins (Marques et al., 1991; Olóriz et al., 1991, 1993, 1996; RodríguezTovar, 1995; Caracuel, 1996).

Studying epioceanic ammonitico rosso from southern Spain, Olóriz et al. (1993, 1995b, 1996) analysed ecostratigraphic and depositional signals in relation to expected trends according to the eustatic curve by Marques et al. (1991; adapted from Haq et al., 1988). Eastwards in the Tethys (Venetian Alps), lithofacies evolution in Upper
Jurassic ammonitico rosso has been investigated by Martire $(1988,1989,1992)$ through the comparative analysis of the facies studied with the expected trends in deposition according to the eustatic curve in Haq et al. (1988). In the case study, assuming the model proposed by Martire (1992) for the Altopiano di Asiago (VI) and on the basis of refined biostratigraphy and correlations (Fig. 5), it is possible to recognize relationships between facies distribution (NMF, NCF, and PSCMF) and expected depositional trends according to third-order eustatic fluctuations proposed by Marques et al. (1991). By analysing megainvertebrate-assemblage evolution, isotopic and geochemical data, as well as taphonomic and ichnologic observations, Caracuel (1996) has supported the validity of the application of the eustatic curve to this case study.

Martire (1989, 1992), and Martire et al. (1991) interpreted hiatuses and hardgrounds in epioceanic plateaux as being controlled by wind-driven currents sweeping off plateau bioclasts during sealevel lows. Even admitting the limitation in recognizing productivity cycles, these authors implies that productivity was crucial to carbonate sedimentation in ammonitico rosso. In Martire's model, sedimentation was restricted to third-order relative sea-level highs. Second-order sea-level fluctuations can be registered as depositional shifts to intraclast-rich limestones during regressive trends, due to more active winnowing of fine particles.

In this study, it is also possible to recognize the effect of relative sea-level fluctuations, through the associated changes in carbonate productivity and hydrodynamics. However, during relative sea-level lows, the combination of deeper bottoms and/or lower energy determined the lack of biostratigraphically recognizable hiatuses in the upper unit of the RAV at Monte Rust. This idea is valid assuming that there are no significant changes in nutrients, productivity, and fine clastic inflows. Thus, we found that relative sea-level highs (deposition of NMF, Uhlandi Subzone and Beckeri Zone in Fig. 5) were related to maximum floodings at the interpreted third-order eustatic cycles ( Haq et al., 1988). These maximum floodings appear to represent lower-energy conditions with little or no possi- 
bility for the winnowing of the scanty fine-grained sediments which reached swell areas at a more or less constant rate. In such a situation, fine clastics would be caught on epioceanic plateaux. In the case of relatively deeper swells, facies comparatively rich in floating bioclasts (i.e., Saccocoma and filaments) also developed. In contlast, during sea-level lows, potentially floating (easily transportable) bioclasts were selectively swept off plateaux, together with fine muddy sediments, as a result of the expected higher-energy conditions. During sea-level highs, there was little sorting or orientation of elongate bioclasts. The recognition of selective sweeping off plateaux was the only effective criterion for identifying active currents in these depositional environments, but this identification was partially obscured by bioturbation and nodulation.

A complementary interpretation based on stable-isotope analyses is available in Caracuel (1996; and unpublished data by J.E. Caracuel and F. Olóriz). The $\delta^{18} \mathrm{O}$ and $\delta^{13} \mathrm{C}$ data obtained from belemnite rostra throughout the sections (cycles 4.5, 4.6, and 1.1 in Fig. 5) show shared trends to lighter values within a total range of $\delta^{13} \mathrm{C}=$ -1.02 to $+1.71 \%$, and $\delta^{18} \mathrm{O}=-1$ to $-0.03 \%$. These data indicate cold temperate waters for the belemnites studied. Moreover, a shared trend is recorded to cooler and lower productivity conditions towards high sea-level. This is in accordance with a low rate of bioclast input during sea-level highs. Nevertheless, two possibilities exist to determine low skeletal content during sea-level highs: (a) lower winnowing of fine-grained sediments; and (b) lower input of skeletals resulting from slower productivity. Whatever the case, depth appears to be a complementary and crucial factor determining the possibility for wind-driven currents to influence deposition.

Despite the fact that the deposition of relatively marly sediments (NMF) is in good agreement with the model by Martire (1989, 1992) for sea-level highs, some deviations have been identified for eustatic or relative sea-level lows. In contrast to the model applied in the Altopiano di Asiago (VI) (Martire, 1989, 1992), deeper and/or lower-energy environments (protected environment in Monte Rust area) favoured the development of relatively calcareous sedimentation ( NCF) during sea-level lows, instead of hiatal deposits, with or without hardgrounds, which characterized higher platform sectors or sites under higher-energy conditions, such as the Altopiano di Asiago (VI). Moreover, in the case at hand, comparatively well-exposed areas, or sites under persistent entergy increases during sea-level lows, should result in the deposition of PSCMF. This facies has been recognized in the lowermost Tithonian (lower Hybonotum Zone). Haq et al. (1988) proposed that this level corresponds to a relative eustatic low (short-term) superimposed on a long-term sea-level high. Taking into account the biotic and abiotic features in the PSCMF, as well as their restricted stratigraphic range (PSCMF are recognized only at the base of the Tithonian in the area), we infer that local factors cancel and even reverse the effects of long-term eustasy, emphasizing those of shortterm eustasy. In short, environmental energy increased when the PSCMF was deposited. Due to this increase, fine sediments were swept off the plateau, and probably ammonite carcasses also by increasing post mortem transport; this could be the reason for the persistent meagre megainvertebrate record in the PSCMF.

The upwards increase in thickness of ammonite biozones in the Lower Tithonian is interpreted as having been caused by the interaction between tectonics and eustasy, starting with deposition of PSCMF (Figs. 3 and 5). This is in accordance with the increased tectonic activity recognized in separate areas during the latest Jurassic (Brookfield, 1970; Hillebrandt, 1973; Hallam, 1978, 1988; Rawson and Riley, 1982; Marques et al., 1991; Salvador et al., 1992).

\section{Conclusions}

Kimmeridgian-Tithonian sections at Monte Rust (MR-1, MR-2), the Forte Austro-Ungarico (FAU), and the Bus di Pissavacca (BDV), provide valuable data for biostratigraphic subdivision and the interpretation of depositional conditions of ammonitico rosso facies.

Nodular-marly, nodular-calcareous, and pseudonodular-calcareous-massive ammonitico rosso 
facies provide reliable information about depositional conditions in the area according to environmental energy, which was related mainly to relative sea-level conditions.

Under generalized low-energy conditions, increasing energy operated during slowing sealevel (regressive phases), determining the deposition of nodular-calcareous ammonitico rosso, and of pseudonodular-calcareous-massive ammonitico rosso under extreme energy conditions, probably related to interactions between tectonics and eustasy. Energy decreased during rising sea level (transgressive phases), leading to the deposition of nodular-marly ammonitico rosso facies.

Numerical analysis (cluster and correlation analysis) of semiquantitative estimations of selected components by microscope shows only minor but recognizable fluctuations in depositional energy, as well as rather variable relationships between micro- and macrofeatures in the ammonitico rosso studied. On this basis, the reverse trends in the record of bioclast orientation, and both the bioturbation and the abundance of easily transportable bioclasts, are in agreement with episodic disturbances of background low-energy conditions.

The relationships interpreted between depositional dynamics and changes in relative sea level is ensured by a zone/subzone level ammonite biostratigraphy, based on more than 1400 specimens collected in situ. During the Kimmeridgian, deposits pertaining to sea-level highs (Uhlandi and Beckeri Chrons) are especially well correlated on the basis of ammonite biostratigraphy and lithofacies. Correlations for deposits affected by the progressive long-term sea-level fall during the Early Tithonian are quite consistent.

\section{Acknowledgements}

This research has been supported by financial contribution from the Spanish-Italian Research Cooperation Programme (Project 18 A), and carried out within the framework of Projects PB91-0733 DGCYT, PICG 343, and the EMMI Group (RNM 0178 Junta de Andalucia, Spain). We are grateful to A. Ceragato for field assistance in Lavarone (Trento), as well as to F. Surlyk (Copenhagen) and A. Hallam (Birmingham) for critical revision of this paper and linguistic assistance. In the final version of this manuscript, the English was looked over by David Nesbitt.

\section{References}

Bernoulli, D., Peters, T., 1970. Traces of rhyolitic-trachitic volcanism in the Upper Jurassic of the Southern Alps. Eclogat Geol. Helv. 63, 609-621.

Bernoulli, D., Peters, T., 1974. Traces of rhyolitic-trachytic volcanism in the Upper Jurassic of the Southern Alps: Reply. Eclogae Geol. Helv. 67, 209-213.

Biju Duval, B., Morel, Y., Baudrimont, A., Bizon, G,, Bizon, J.J., Borsetti, A.M., Burollet, P.F., Clairefond, P., Clauzon, G., Colantoni, P., Mascle, G., Montadert, L., Perrier, R., Orsolini, P., Ravenne, C., Taviani, M., Winnock, E., 1983. Exemples de sédimentation condensée sur les escarpements de la Mer Ionienne (Méditerranée Orientale) - Observations à partir du submersible "Cyana". Rev. Inst. Fr. Pét. 38 (4), 427-438.

Bosellini, A., Martinucci, M., 1975. Annegamento delle piattaforme carbonatiche. Ann. Univ. Ferrara, IX (5), (10), 181-193.

Bosellini, A., Winterer, E.L., 1975. Pelagic limestones and radiolarites of the Tethyan Mesozoic: A genetic model. Geology 3, 279-282.

Brookfield, M.E., 1970. Eustatic changes of sea-level and orogeny in the Jurassic. Tectonophysics $9,347-363$

Caracuel, J.E., 1996. Asociaciones de megainvertebrados, evolución ecosedimentaria e interpretaciones ecoestratigráficas en umbrales epioceánicos del Tethys Occidental (Jurásico Superior). Ph.D. Thesis, Dissertation, University of Granada, Granada, $\mathrm{i}-\mathrm{x}+474 \mathrm{pp}$.

Castellarin, A. (coll. Ferrari, A.), 1972. Evoluzione paleotettonica sinsedimentaria del limite tra "Piattaforma Veneta" e "Bacino Lombardo", a nord di Riva del Garda. G. Geol. II 38 (1), 11-212.

Cecca, F., Cresta, S., Pallini, G., Santantonio, M., 1990. Il Giurassico di Monte Nerone (Appennino marchigiano, Italia Centrale): biostratigrafia, litostratigrafia ed evoluzione paleogeografica. In: Pallini, P.A., Cecca, F., Cresta, S., Santantonio, M. (Eds.), Atti del Secondo Convegno Internazionale Fossili, Evoluzione, Ambiente. Pergola, pp. 63-139.

Cecca, F., Fourcade, E., Azèma, J., 1992. The disappearance of the "Ammonitico Rosso". Palaeogeogr., Palaeoclimatol., Palaeoecol. 99, 55--70.

Clari, P., Pavia, G., 1987. Superfici di interruzione di sedimentazione e lacune biostratigrafiche nel Cretaceo inferiore di Mizzole (Lessini Veronesi). Boll. Soc. Paleontol. Ital. 26 (1/2), $21-38$

Dromart, G., Atrops, F., 1988. Valeur stratigraphique des biomicrofaciès pélagiques dans le Jurassique supérieur de la 
Téthys occidentale. C.R. Acad. Sci., Paris 306 (II), $1365-1371$.

Enay, R.. Geyssant. J.R., 1975. Faunes tithoniques des chaines betiques (Espagne méridionale). In: Colloque sur la limite Jurassique-Crètacé, Lyon-Neuchâtel. Mém. Bur. Rcch. Géol. Min. 86, 39-55.

Farinacci, A., Elmi, S. (Eds.), 1981. Rosso Ammonitico Symposium Proceedings. Tecnoscienza, Rome, 602 pp.

Ferrari, A., 1982. Note stratigrafiche sull area veneto trentina (dal Triassico superiore al Cretacico). In: Castellarin, A., Vai, G.B. (Eds.), Guida alla geologia del Sudalpino centroorientale. Guide Geol. Reg., Soc. Geol. Ital., pp. 5966.

Fözy, I.. 1990. Ammonite succession from three Upper Jurassic sections in the Bakony Mts. (Hungary). In: Pallini, P.A., Cecca, F., Cresta, S., Santantonio, M. (Eds.). Atti del Secondo Convegno Internazionale Fossili, Evoluzionc, Ambiente. Pergola, pp. 323339

Hallam, A., 1978. Eustatic cycles in the Jurassic. Palaeogeogr., Palaeoclimatol., Palaeoecol. 23, 1-32.

Hallam, A.. 1988. A reevaluation of Jurassic custasy in the light of new data and the revised Fxxon curve. In: Wilgus, $\mathbf{C}$. Hastings, B.S., Kendall, C.G.St.C., Posamentier, H.W.. Ross. C.A., Van Wagoner, J.C. (Editors), Sea-Level Changes - An Integrated Approach. Soc. Econ. Paleontol. Mineral., Spec. Publ. 42. 261-274.

Hantzpergue, P., Atrops, F.. Enay, R., 1991. Kimmeridgien. In: Réactualisation des échelles d Ammonites. 3rd Int. Symp. on Jurassic Stratigraphy, Poitiers, p. 133

Haq, B.U., Hardenbol, J., Vail, P.R., 1988. Mesozoic and Ceno zoic chronostratigraphy and eustatic cycles. In: Wilgus, C.K.. Hastings, B.S., Kendall. C.G.St.C. Posamentier, H.W., Ross, C.A., Van Wagoner, J.C. (Eds.), Sea-Level Changes - An Integrated Approach. Soc. Econ. Paleontol. Mineral., Spec. Publ, 42, 7189.

Hillebrandt, A.V., 1973. Neue Ergebnisse über den Jura in Chile und Argentinien. Münster Forsch. Geol. Paläontol. 31:32. $167-199$.

Hollmann, R., 1962. Über Subsolution und die "Knollenkalke" des Calcare Ammonitico Rosso Superiore im Monte Baldo (Malm: Norditalien). Neues Jahrb. Geol. Paläontol., Monatsh., pp. 163-179.

Hollmann, R.. 1964. Subsolutions-Fragmente (Zur Biostratinomic der Ammonoidea im Malm des Monte Baldo/Norditalien). Neues Jahrb. Geol. Paläontol., Abh. 119 (1), 2282.

Marques, B., Olóriz, F., Rodriguez-Tovar, F.J., 1991. Interactions between tectonics and eustasy during the Upper Jurassic and lowermost Cretaccous -... Examples from the South of Iberia. Bull. Soc. Géol. Fr. 162 (6), 10091024.

Martire, L., 1988. Età, dinamica deposizionale c possibile organizzazione sequenziale del Rosso Ammonitico dell' $\mathrm{Al}$ topiano di Asiago (VI). Rend. Soc. Geol. Ital. 11, 231-236.

Martire, L., 1989. Analisi biostratigrafica e sedimentologica del Rosso Ammonitico Veronese dell'Altopiano di Asiago (VI). Ph.D. Thesis, Dissertation, University of Torino, Torino, $166 \mathrm{pp}$.

Martire, L., 1992. Sequence stratigraphy and condensed pelagic sediments -- An example from the Ammonitico Rosso Ver- onese, northern Italy. Palaeogeogr., Palaeoclimatol., Palaeoccol. 94, 169.191.

Martire, L., Clari, P.A., Pavia, G., 1991. Il significato stratigrafico della sezione di Cima Campo di Luserna (Giurassico delle Alpi Meridionale, Italia nord orientale): Palaeopelagos 1, 56-65.

Massari, F., 1981. Crypyalgal fabrics in the Rosso Ammonitico sequences of the Venetian Alps. In: Farinacci, A., Elmi, S. (Eds.), Rosso Ammonitico Symposium Proceedings. Tecnoscienza. Rome. pp. 435-469.

Massari, F., 1983. Oncoids and stromatolites in the Rosso Ammonitico sequences (Middle-Upper Jurassic) of the Venetian Alps, Italy. In: Peryt. T.M. (Ed.). Coated Grains. Springer, Berlin, pp. 358-366.

Müller, J., Fabricius, F., 1974. Magnesian-calcite nodules in the Ionian deep sea: an actualistic model for the formation of some nodular limestones. In: Hsü. K.J., Jenkyns, H.C. (Eds.), Pelagic Sediments: On Land and Under the Sea. Int. Assoc. Sedimentol., Spec. Publ. 1, 235247.

Mullins, H.T., Newmann, A.C.. Wilber, R.J., Boardman, M.R. 1980. Nodular carbonate sediment on Bahamian slopes: Possible precursor to nodular limestones. J. Sediment. Petrol. $50(1), 117131$

Olóriz, F., 1978. Kimmeridgiense--Tithonico inferior en el sector central de las Cordilleras Béticas (Zona Subbética) Paleontologia - Biostratigrafia. Ph.D. Thesis, Dissertation, University of Granada, Granada, 184, i-xvii +758 pp.

Olóriz. F.. Tavera, J.M., 1981. El Jurásico Superior en el Sector Central de la Zona Subbética Introducción al conocimiento de las facies -. Indices y correlaciones. R. Acad. Cien. Fís. Nat., PIGC 2, 207239.

Olóriz, F., Tavera. J.M.. 1989. The significance of Mediterranean ammonites with regard to the traditional Jurassic-Cretaceous boundary. Cretaceous Res. 10. 221237.

Olóriz, F.. Marques, B., Rodriguez-Tovar, F.J., 1991. Eustatism and faunal associations - Examples from the South Iberian matgin during the Upper Jurassic (Oxfordian-Kinmeridgian). Eclogae Geol. Helv. 84 (1), 83-106.

Olóriz, F., Rodriguez-Tovar, F.J., Marques, B., Caracuel, J.E., 1993. Ecostratigraphy and sequence stratigraphy in high frequency sea level fluctuations: Examples from Jurassic macroinvertebrate assemblages. Palaeogeogr., Palaeoclimatol., Palaeoecol. 101, 131-145.

Olóriz, F., Caracuel, J.E., Marques, B., Rodríguez-Tovar. F.J., 1995a. Asociaciones de tintinnoides en facies ammonitico rosso de la Sierra Norte (Mallorca). Rev. Esp. Paleontol., No. Homen. Dr. G. Colom, pp. 77-93.

Olóriz, F., Caracuel, J.E., Ruiz-Heras, J.J., 1995b. Numerical analysis of sedimentary components: A key for interpretation of macroscopic and microscopic features in $\Lambda$ mmonitico Rosso facies ( Uppermost Jurassic-Lowermost Cretaceous). J. Sediment. Res. A65 (1), 234243.

Olóriz. F.. Caracuel, J.E.. Ruiz-Heras, J.J.. Rodríguez-Tovar, F.J., Marques, B., 1996. Ecostratigraphic approaches, sequence stratigraphy proposals and block tectonics: Examples from epioceanic swell areas in South and East lberia. Palaeogeogr.. Palaeoclimatol., Palaeoecol. 121, 273295. 
Rawson, P., Riley, L.A., 1982. Latest Jurassic-Early Cretaceous Events and the "Late Cimmerian Unconformity" in North Sea Area. Am. Assoc. Pet. Geol. Bull. 66 (12), 2628-2648.

Rodriguez-Tovar, F.J., 1995. Evolución sedimentaria y ecoestratigráfica en plataformas epicontinentales del margen Sudibérico durante el Kimmeridgiense inferior. Ph.D. Thesis, Dissertation, University of Granada, Granada, $\mathrm{i}-\mathrm{x}+374 \mathrm{pp}$.

Salvador, A., Westermann, G.F.G., Olóriz, F., Gordon, M. B., Gursky, H.-J., 1992. Meso-America. In: Westermann, G.E.G. (Ed.), The Jurassic of the Circum-Pacific. Cambridge University Press, New York, NY, pp. 93-121.

Sapunov, I.G., 1977a. Ammonite stratigraphy of the Upper Jurassic in Bulgaria, III. Kimmeridgian: Substages, zones and subzones. Geol. Balcanica 7 (1), 63-80.

Sapunov, I.G., 1977b. Ammonite stratigraphy of the Upper Jurassic in Bulgaria, IV. Tithonian: Substages, zones and subzones. Geol. Balcanica 7 (2), 43-64.

Sarti, C., 1985. Biostratigraphie et faune à ammonites du Jurassique supérieur de la plate-forme atesine (Formation du Rosso Ammonitico Véronais). Rev. Paléobiol. 4 (2), $321-330$.

Sarti, C., 1986. Fauna e biostratigrafia del Rosso Ammonitico del Trentino centrale (Kimmeridgiano-Titoniano). Boll. Soc. Paleontol. Ital. 23 (3), 473514.

Sarti, C., 1988. Biostratigraphic subdivision for the Upper Jurassic of the Venetian Alps (northern Italy) on the base of ammonites. 2nd Int. Symp. on Jurassic Stratigraphy, Lisbon, pp. 459-476.

Sarti, C., 1993. Il Kimmeridgiano delle Prealpi Veneto-Trentine: Fauna e Biostratigrafia, Mem. Mus. Civ. Stor. Nat. Verona, (II Ser.) Sez. Sc. Terra 5, 145 pp.

Tavera, J.M., Aguado, R,, Company, M., Olóriz, F., 1994. Integrated biostratigraphy of the Durangites and Jacobi Zones ( $\mathrm{J} / \mathrm{K}$ boundary) at the Puerto Escaño section in Southern Spain (Province of Córdoba). Geobios, Mém. Spec. $17,469-476$

Vail, P.R., Colin, J.P., Jan Du Chêne, R.J., Kuchly, J., Mediavilla, F., Trifilieff, V., 1987. La stratigraphie séquentielle et son application aux corrélations chronostratigraphiques dans le Jurassique du bassin de Paris. Bull. Soc. Géol. Fr. 8/III (7), 1301-1321.

Winterer, E.L., Bosellini, A., 1981. Subsidence and sedimentation on a Jurassic passive continental margin, southern Alps, Italy. Am. Assoc. Pet. Geol. Bull. 65, 394-421.

Zempolich, W.G., 1993. The drowning succession in Jurassic carbonates of the Venetian Alps, Italy: A record of supercontinent breakup, gradual eustatic rise, and eutrophication of shallow-water environments. In: Loucks, R.G., Sarg, J.F. (Eds.), Carbonate Sequence Stratigraphy: Recent Developments and $\Lambda$ pplications. Am. Assoc. Pet. Gcol., Mcm. 57, 63-105. 